\section{SELF-REVELATION AND CONCEALMENT IN CAESAR'S DE BELLO GALLICO: CICERO, ORGETORIX, AND THE BELGAE}

* Universidade Federal de Santa Catarina

\begin{abstract}
Building on the work of others who have seen an allusion to the First Triumvirate in the tripartite Gallic conspiracy led by Orgetorix, this article shows how Caesar reveals himself as formidable between the lines of $\mathrm{De}$ bello Gallico, and particularly in its famous opening.
\end{abstract}

KEYWORDS: Julius Caesar, De bello Gallico, First Triumvirate, Cicero.

\section{AUTORREVELAÇÃO E DISSIMULAÇÃO NO DE BELLO GALLICO DE CÉSAR, CÍCERO, ORGETORIX E OS BELGAS}

RESUMO: Baseando-se no trabalho de outros estudiosos que viram uma alusão ao Primeiro Triunvirato na tripartite conspiração gálica comandada por Orgétorix, este artigo mostra como César se revela como alguém formidável nas entrelinhas da obra De bello Gallico, e particularmente em sua famosa abertura.

PALAVRAS-CHAVE: Júlio César, De bello Gallico, Primeiro Triunvirato, Cícero.

\section{INTRODUCTION}

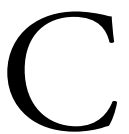

aesar apparently delays his "entrance into history." Although by no means hesitant to make himself conspicuous in De Bello Gallico, ${ }^{2}$ he mentions himself for the first time at 1.7.1, using the dative form Caesari. Even at 1.7.1, then, it is only after information

\footnotetext{
The reference is to Strasburger 1938.

${ }^{2}$ De Bello Gallico 7.88.1. References will be to $\mathrm{Du}$ Pontet 1890, and will be cited by book, chapter, and section numbers alone.
} 
${ }^{3}$ The rival claims of Massilia and Narbo are discussed in Holmes 1911, p. 3-4.

${ }^{4}$ 1.1.3. Unless otherwise indicated, all translations are my own.

${ }^{5}$ See Torigian 1998 , p. 46-47.

${ }^{6}$ Fränkel 1955, p. 304: "Die Parallele mit Caesars eigenem Aufstieg liegt um so näher, als zu Orgetorix' Unternehmen auch ein

Triumvirat mit zwei anderen Männern gleichen Schlages gehört, dessen Ziel die Beherrschung Galliens war (1.3.8).”

Gerhard 1991, p. 271: "il faut examiner le parallélisme frappant, quique jamais encore étudié, entr la coalition des trios princes gaulois et le triumvirat de César, Pompée et Crassus.”

${ }^{8}$ Gerhard 1991, p. 273:

"6. L'echec de la coalition. Orgétorix, dénoncé, inculpé, incarcéré, mourut en prison $(1,4)$. Le triumvirat de Cesar, Pompée et Crassus, s'il ne connut pas une fin analogue, était en réalité dissous lors de la rédaction du Bellum Gallicum, en 52 ou 51." The attached note cites Michel Rambaud, pioneer of the critical reading of Caesar's commentaries. "Le mort en couches de Julia en septembre 54 puis celle de Crassus en juin 53 rompirent l'alliance entre César et Pompée, et déclenchèrent l'hostilité que déboucha la guerre civile." The parallel has come "to Caesar" that he assumes his characteristic role as the subject of three verbs-parallel to his more famous triplet veni, vidi, vici-maturat, contendit, and pervenit. The fact that his first entrance is marked by precisely three verbs reminds us of his book's famous opening sentences, where triads multiply: Gaul has been divided into three parts (1.1.1), its inhabitants differ among themselves in three respects (1.1.2), and three rivers are required to divide them geographically (1.1.2). Moreover, when Caesar explains why the Belgae are the strongest/bravest of them all (fortissimi omnium), he gives three reasons for their strength in 1.1.3: (1) their greater distance from the cultus and humanitas of the Roman Province of Narbonese Gaul, ${ }^{3}$ (2) the fact that merchants seldom come among them, importing "those things that pertain to effeminizing spirits," ${ }^{\prime 4}$ and (3) they are continuously waging war with their neighbors, the Germans. In addition to seeing these triads as signs of careful composition in general, 5 I will argue more specifically in this paper that it was Caesar's intention to reveal what I will call his "formidable" position among the secret conspiracy of Crassus, Pompey, and Caesar, known to posterity as "the First Triumvirate," and will furthermore suggest that this intention should be considered in the context of Caesar's rivalry not only with his fellow-triumvirs, but with Cicero.

\section{THE DIALECTIC OF SELF-REVELATION AND CONCEALMENT}

Following a hint from Hermann Fränkel, ${ }^{6}$ Yves Gerhard argued in his path-breaking 1991 article "Orgétorix l'Helvète et la Bellum Gallicum de César" that the conspiracy of Orgetorix the Helvetian, Dumnorix the Aeduan, and Casticus the Sequanian was an allusion to the First Triumvirate. ${ }^{7}$ Gerhard remarks six important parallels: (1) the secret character of the alliance, (2) the chronological simultaneity of the two triads, (3) the common goal of the two conspiracies, i.e., the achievement of kingly power (regnum), (4) the use of marriage for a political goal in both, (5) a common appeal to the people against the aristocracy, and (6) the eventual defeat of the coalitions. ${ }^{8}$ Before 
modifying Gerhard's conclusions, particularly with regard to "(6)," it is important to state that I fully endorse his approach and intend to extend it. Admiring Gerhard, I also note with pleasure that Catherine Torigian ${ }^{9}$ cites his article in the important collection Julius Caesar as Artful Reporter and, more recently, so does Randy Fields, ${ }^{10}$ yet another high school Latin teacher. ${ }^{11}$

There is good reason for this connection: high school Latin teachers are accustomed to begin at the beginning, and it is in the famous opening words of Caesar's De Bello Gallico that the curious dialectic between concealment and self-revelation that is my subject first appears. To begin with, the use of the word "dialectic" suggests philosophy and Caesar introduces dialectic in this sense by the words Gallia est omnis divisa in partes tres. The philosophical dialectic in play here is, or rather involves, the ancient problem of the One and the Many: if Gaul is actually one, i.e., if there exists such a thing as Gallia omnis, then "it" is not divided into many parts. On the other hand, if it is essentially "divided," then it is not one. Impatient of philosophical conundrums, we reply that it is obviously both: hence the applicability of the word "dialectic." With the word "dialectic" having been justified, then, the dialectic of self-revelation and concealment is implicit in the words divisa est. Nothing would be easier than to tell the budding Latinist that these words mean: "Gaul is divided." But if the intent is actually to teach Latin, then these words must be recognized as the classic example of the perfect passive: as a matter of grammar, then, "Gaul has been divided." 12 To delve a bit further into the subterranean simplicities that are the lowly high school teacher's stock in trade, the verb dividere does not involve an act of what we would call "dividing" (i.e., cutting, splitting, or separating) but rather, primarily, an act of "seeing": Gaul has been seen in its discrete, distinct, (pardon the etymological neologisms:) dis-verse, and indeed dis-ferent parts. But "having been seen" (as dis-tinct and dis-visible) by whom? Certainly not by the Romans: there is no reference here to Cisalpine, Narbonese, and the non-Roman "hairy" or "trouser-wearing" Gaul beyond it - the obvious triad from a contemporary Roman's perspective-but instead, the two parts of Gaul between Orgetorix giving his daughter in marriage to Dumnorix and Caesar giving Julia to Pompey would have been the decisive clue for a Roman reader and should be so as well for us; see Gerhard's fourth parallel at 272 .

${ }^{9}$ Torigian 1998, p. 60 n. 14 and 52-53: "Yet such connections as he [sc.

Gerhard] makes between

Orgetorix and Caesar are, in Gerhard's own opinion, insufficient grounds for Caesar's inclusion of the Orgetorix story, and Gerhard ends his study with the admission that he does not know why the episode is there. The notion of a parallel triumvirate is indeed a captivating one, but it does not take into consideration the presence of a rhetorical link between Orgetorix' thinking and Caesar's own which reveals how inclusion of the episode serves Caesar's

propagandistic goals. The link is established when a statement pronounced initially in Caesar's voice reappears as oratio obliqua [cf. following note] in the mouth of Orgetorix."

${ }^{10}$ Fields 2005, p. 20 n. 61. This citation is attached to the following sentence:

"The speech is framed by Orgetorix' exhortation to assume supreme command (Caesar uses a form of the word regnum three times in the narrative surrounding Orgetorix' speech), and immediately before the speech, the Helvetian king arranges the marriage of his daughter to Dumnorix, 
a political arrangement that undoubtedly recalled

to Caesar's audience the parallel Roman arrangement between Caesar and Pompey [n. 61].”

${ }^{11}$ Fields teaches Latin at a private high school in Atlanta, Torigian is an experienced secondary school Latin teacher, formerly of the Browning School, and GERHARD teaches Latin at the Gymnasium 'Les Cloches' in Lausanne.

${ }^{12}$ Kraner, Dittenberger, and Meusel (ad loc.) cites 6.16.1 as a parallel; more pertinent is 1.4.1.

${ }^{13}$ Given Caesar's implicit but disguised agency in dividing Gaul, it is tempting to consider the opening words of De Bello Gallico as the simultaneous revelation and concealment of an arcanum imperii. Vogt 1960 explores the implications of the interesting fact that the words "divide et impera" (see the humorous note at 211 n. 29) are not to be found in classical Latin literature. Unfortunately, Vogt attempts to explain this lacuna by denying that the Romans made a conscious practice of this policy; rejecting the commonsense dialectic of "first divide, then unite" (see Vogt's citation of F. E. Adcock at 210 n. 26), he argues that dividing enemies was at most an "instinct" (210 and 218) and that already divided enemies-Gaul is his principal example

(207-8)_made Roman unification possible. that every Roman knows (Cisalpine and Narbonese Gaul) are ignored while that distant Transalpine Gaul-well beyond the Roman provincia-has been seen by an unnamed someone as not only being "all Gaul," but also as divided into three parts. Quite apart, then, from exposing his readers to the dialectic of the One and the Many, Caesar is not only revealing himself to be the missing ablative of agent by whom Gaul "has been divided" in a totally unfamiliar, and indeed in a non-Roman way, ${ }^{13}$ but has unquestionably concealed himself as this secret agent. In short: introduced in the dative in 1.7 (Caesari cum id nuntiatum esset), Caesar has already both revealed and concealed himself as the missing ablative of agent in 1.1. This, then, constitutes the first example of the dialectic of revelation and self-concealment in play here; indeed no earlier example would be possible, given that this is how Caesar chose to begin his text. I will suggest that he did so in order to make himself "formidable."

\section{CAESAR AS "FormidAble”}

The patent purpose of the first six chapters of $D e$ Bello Gallico Book I is to explain the Helvetian migration as a threat to Rome, and thus to justify Caesar's apparently defensive actions in response. It is therefore significant that Caesar derives the threat posed by the Helvetians from their similarity to the Belgae. This is at first sight curious: the Belgae are the first of the three parts of his newly divided Gaul that Caesar chooses to discuss, but the Helvetiansthe primary subject of Book I-are not Belgae, who only take center stage in Book II. And there is another problem: there is no pressing need for Caesar to mention Orgetorix at all here, because by the time of the threatening Helvetian migration, Orgetorix is already dead. But there is even less reason-unless, that is, we are prepared to find "reason" in Caesar's conscious dialectic of self-revelation and concealment-to introduce the Belgae at this early stage. My claim is that he does so for the same reason that he is writing De Bello Gallico in the first place: in order to make himself fearsome or "formidable" (L. formidabilis) in a Rome 
that, thanks to the Triumvirate, already "has been divided into three parts." Before identifying himself with the dead Helvetian architect of what I will call "the Gallic Triumvirate" - the "historical" Orgetorix (whose only actual claim to historical significance is that he was the instigator of the Helvetian migration that is now being undertaken without him, after his death) —Caesar links the Helvetians to the strongest inhabitants of his own tripartite or rather self-divided three-fold Gaul. Having first divided Gaul into three parts in accordance with his own conceptions and purposes, he incongruously turns next to the distinctive excellence of the Belgae, a topic with no conceivable relevance to Book I. And having explained their excellence by yet another triad (i.e., distance from the province, paucity of imported luxuries, and continuous fighting with Germans), he derives the formidability of the Helvetians-which of course is highly relevant to Book I-from the Belgae by means of the last of these explanations. I want to show that the second step in Caesar's concealed self-revelation is the otherwise illogical emphasis he places on the Belgae.

Of all these, the bravest-strongest [fortissimi] are the Belgians, on account of the fact that they are farthest removed from the culture and humanity [humanitate] of our province and least often to them do merchants come, importing those things that pertain to the effeminizing of spirits [ad effeminandos animos], and because they are nearest to the Germans who dwell across the Rhine, with whom they continuously wage war. For which reason, the Helvetii also surpass the other Gauls in virtue $[$ virtute $] ..{ }^{14}$

\section{CAesAR AND CICERO ON VIRTUS AND hUMANITAS}

The crucial trope in Caesar's description of the Belgae is the sharp division between virtus and humanitas: to begin with, the Belgae are fortissimi because they are farthest away from humanitas. The words Caesar uses to describe the Belgae indicate the ghostly presence of another of Caesar's rivals: Cicero. The literary phase of this competition begins with de Bello Gallico, and Caesar's attempt to divorce virtus from humanitas in his description of the Belgae is best understood in the context of Cicero's Pro Archia (62 B.C.).
It seems more likely that the curious coincidence of this maxim's repeated application and its literary absence indicates that whatever other errors are to be found in Hohl 1933, he was correct to conclude that divide et impera was an arcanum imperii (144; cf. Vogt 1960, p. 200 n. 7 and 213). This would then constitute another example of Caesar's selfrevelation and concealment.

${ }^{14}$ Caesar, de Bello Gallico 1.1 (translation mine); see McDonnell 2006, p. 300-2 and Riggsby 2006, p. 83-90 for Caesar's conception of virtue. 
${ }^{15}$ Cicero pro Archia 1.2.19-21; cf. 3.4.19; references to pro Archia include line-numbers based on Clark 1911.

${ }^{16}$ Cicero pro Archia 6.12.7-11.

${ }^{17}$ Cicero pro Archia 7.15.19-27.
In a pertinent linguistic echo, Caesar reverses the meaning of the following sentence in Cicero's speech when pointing out the absence among the Belgae of ea quae ad effeminandos animos pertinent: Etenim omnes artes, quae ad humanitatem pertinent, habent quoddam commune vinculum, et quasi cognatione quadam inter se continentur. ${ }^{15}$ In addition to the fact that Cicero must depend throughout on the jury's humanitas (pro Archia 2.3.9 and 12.31.13-14), his defense of literature also involves supplementing manly animi, not undermining them/it:

An tu existimas aut suppetere nobis posse quod cotidie dicamus in tanta varietate rerum, nisi animos nostros doctrina excolamus; aut ferre animos tantam posse contentionem, nisi eos doctrina eadem relaxemus? Ego vero fateor me his studiis esse deditum. ${ }^{16}$

As this last sentence indicates, Cicero is aware that a defense of literature can be made to seem un-Roman, and Caesar knew well how to exploit this sentiment. But Cicero's defense is strong enough to have put Caesar on the defensive (8.17.15-16): Quis nostrum tam animo agresti ac duro fuit ut Rosci morte nuper non commoveretur? Clearly Caesar's Belgae would not be so moved. But Cicero's chief weapon is not the ridicule reserved for those who are longissime absunt a cultu atque humanitate but rather a reasonable and moderate blending of virtus and humanitas:

Ego multos homines excellenti animo ac virtute fuisse, et sine doctrina naturae ipsius habitu prope divino per se ipsos et moderatos et gravis exstitisse, fateor: etiam illud adiungo, saepius ad laudem atque virtutem naturam sine doctrina quam sine natura valuisse doctrinam. Atque idem ego contendo, cum ad naturam eximiam atque inlustrem accesserit ratio quaedam conformatioque doctrinae, tum illud nescio quid praeclarum ac singulare solere exsistere. ${ }^{17}$

It is against this Ciceronian synthesis that Caesar responds in his self-revealing description of the Belgae. It is further noteworthy that Caesar's disjunction between virtus and humanitas is sexualized: since the luxuries imported by merchants contribute ad effeminandos animos, the masculine element in virtus is emphasized. As a whole, 
then, the passage argues that the Belgae, and by extension the Helvetii, are manly while those closer to Romewhether these be Gauls or Caesar's fellow Romans-are effeminized by this proximity and its effects. It is, then, as the Roman analogue of the Belgae that Caesar makes his second appearance. Indeed his first appearance (as the concealed agent ablative of divisa est) yields its first harvest precisely by permitting Caesar to suggest that it is he, alone among the Romans, who is fortissimus, just as the Belgae are fortissimi among those who inhabit Gaul. It is Caesaras opposed to Pompey and Crassus in particular-who is farthest removed from the culture of Rome: he is not only at present living beyond the reach of the luxuries that effeminize his rivals, but he is also fighting those who have fought the Germans, and soon enough, in the person of Ariovistus, he will himself be fighting Germans as well. But in this first triad, Caesar makes no effort to distinguish himself from Pompey and Crassus, as he will do later in the case of the Gallic Triumvirate: no details about the Aquitani or Celtae/Galli are offered to the reader here. It is therefore tempting to say that Caesar's sole purpose in lavishing attention on the formidable Belgae is to begin the process of distinguishing Caesar himself as "formidable" by explaining his conception-his frightening conception, it should be added—of what makes a man fortis.

\section{Caesar, ANAlogy, AND the GALlic triumVirate}

The Helvetian revolutionary Orgetorix is the first person mentioned in Caesar's De Bello Gallico: Apud Helvetios longe nobilissimus fuit et ditissimus Orgetorix (1.2.1). The Belgae are longissime absunt, Orgetorix is longe nobilissimus; so much for intra-textual linguistic analogy. As far as the extra-textual analogy between Caesar and Orgetorix is concerned-and it is worth mentioning that Caesar was an expert on analogy ${ }^{18}$ Caesar is, from the start, making himself more formidable than he actually was: ditissimus applies to him much less than nobilissimus, ${ }^{19}$ at least, that is, at the start of the campaign in Gaul. But then again, he does not claim that Orgetorix was longe ditissimus; even in his exaggerations, he seems conscious
18

${ }^{19}$ Beginning with the sentence: "The origin of the Iulii was shrouded in myth deriving their ancestry from Aeneas and Venus long before the age of Caesar" (11), Badian 2009 deserves careful attention. 
of the need for a certain, if severely limited, degree of verisimilitude. The important thing to be learned here is (1) that "formidable" has a double meaning, and (2) that Caesar is willing to exaggerate his formidability. In the face of foes, "formidable" should be taken in its etymological purity: Caesar is willing to exaggerate in order to make himself appear to be terrifying. But he is also writing for friends, and for those, the French word formidable applies: he is both (as in colloquial English) "awesome" (for his friends) and "awful" to his foes. In addition to encouraging his supporters with the belief that he can afford to reward them generously, Caesar's ditissimus inaugurates a curious but ongoing suppression of the man who had once paid his debts: M. Licinius Crassus (Suetonius, Caesar 18.1, Plutarch, Life of Caesar, 11.2-3, Life of Crassus 7.6, and Appian, Civil War, 2.27).

Is, M. Messala et M. Pupio Pisone consulibus, regni cupiditate inductus coniurationem nobilitatis fecit, et civitati persuasit ut de finibus suis cum omnibus copiis exirent: perfacile esse, cum virtute omnibus praestarent, totius Galliae imperio potiri. (Caesar, De Bello Gallico, 1.2.1-2).

Since Orgetorix simply does not exist outside of the pages of Caesar's De Bello Gallico, it hardly matters that he lies to his people: although the Helvetians may well surpass the remaining Gauls in virtue (1.1.4), he elides the Belgae. More importantly, Orgetorix tells the people that he aims to do what Caesar actually did: gain the imperium of all Gaul. In this light, Orgetorix become the inevitable third form in which Caesar both appears and disappears in the opening pages of de Bello Gallico. In the case of Orgetorix, the promise of this imperium is strictly for popular consumption: his real goal is to secure kingly power for himself, and Caesar's De Bello Gallico is a monument to an analogous truth about himself. In this light, Caesar's De Analogia should not be judged entirely lost: just as Caesar can only become first man in Rome by leaving Rome and conquering "all Gaul," so also can Orgetorix only secure his regnum by leaving his homeland behind. The conquest of tota Gallia is merely a means to an end for both, and that end is regnum. But the word "both" does not really 
apply. Just as the division of Gaul into three parts cannot conceal the fact that all Gaul is actually one, so also the invention of the completely unnecessary Orgetorix-the Helvetians are on the move in 58 B.C. even though Orgetorix is dead-is Caesar's way of allowing Caesar to dominate De Bello Gallico even before he mentions himself for the first time at 1.7. In describing or rather by recreating Orgetorix, then, Caesar is actually describing himself. And Caesar's most famous book-like the speech of Orgetorix to its Helvetian counterpart-is Caesar's speech to his own, i.e., to the Roman civitas. Funny for his friends, terrifying to his foes, Caesar's formidability is announced in the jocular threat of his book's deceptive opening word: Caesar's concern is not Gallia: thanks to the Triumvirate of which he is part, the truth of the matter is rather that Roma est omnis divisa in partes tres.

Even though Caesar's detailed treatment of "the Gallic Triumvirate" will be delayed until 1.3.4-5, it has really been his subject from the start. Announced by the multiplying triads of 1.1.1-3, the Triumvirate reappears when the triads return in the context of Orgetorix. In addition to the three geographical features that confine the Helvetians,${ }^{20}$ the plan of Orgetorix is based on the most significant of political triads: the interplay of monarchy, oligarchy, and democracy. ${ }^{21}$ As befits a descendent of Venus, Caesar employs his analogue Orgetorix to inform us that "he" is motivated by cupiditas: an erotic passion for kingly power (regnum). Having situated himself in relation to monarchy, he introduces the Triumvirate for the second of three times: it is a coniuratio nobilitatis. More importantly, like the triad-completing civitas that he will persuade by democratic means, ${ }^{22}$ this coniuratio is merely a means to an end. But it is also something more: it is the means by which the dream of Orgetorix will survive his death. Although Caesar does not name the noble co-conspirators of the dead Orgetorix, the fact that the Helvetian state carries on the project that these men surreptitiously promulgated, proves conclusively that a coniuratio can survive the death of its founder. This observation will prove to be significant.
${ }^{20} 1.2 .3$ (triad annotated): Id hoc facilius iis persuasit, quod undique loci natura Helvetii continentur: [1] una ex parte flumine Rheno latissimo atque altissimo, qui agrum Helvetium a Germanis dividit; [2] altera ex parte monte Iura altissimo, qui est inter Sequanos et Helvetios; [2] tertia lacu Lemanno et flumine Rhodano, qui provinciam nostram ab Helvetiis dividit.

${ }^{21}$ Cf. Herodotus 3.80-83.

${ }^{22}$ The reference to the Social Democratic bogey in pre-War Germany at Kraner, Dittenberger, and Meusel 1913, p. 85 is tragic-comic in retrospect with tragedy dominating with respect to the note as a whole. 


\section{CAESAR'S INTENTION}

For the present, Caesar leaves no doubt that Orgetorix is the architect of the conspiracy. He also leaves no doubt as to the timing: the second and third individuals mentioned in de Bello Gallico are the Roman Consuls who allow Caesar's readers to date the origin of the Helvetian conspiracy to 61 B.C. In the context of the Roman Triumvirate, it is easy to see that Caesar is lying: the Roman Orgetorix probably did not initiate the analogous conspiracy and, regardless of who did, it was probably not formed in 61 B.C. On the other hand, it is impossible to prove either statement: that's the thing about conspiracies. In other words: we simply do not know who initiated the plan for "the First Triumvirate" or when it finally came together. Caesar's apologists are particularly useful here: Erich S. GRUEN in particular does whatever he can to delay its formation and our scanty information - it was a secret, after

${ }^{23}$ See Gruen 2009, p. 31 . all-allows him to do so. ${ }^{23}$ But this lack of data cuts the other way: if we have no solid grounds for refusing to allow GRUEN to push the date forward from the traditional 60 B.C. to 59, we likewise have no solid grounds for refusing to allow Caesar's Helvetian analogy to push the date back to 61. After all, Caesar is the only one of the three Triumvirs who can still speak to us through the written word, and his book De Bello Gallico is the closest in time to the formation of the Triumvirate. In short: as one of only three who knew the truth about that formation, and moreover as the only one of them who may have revealed-if the HelvetianRoman analogy is entertained-its secret circumstances, his testimony deserves careful consideration. And that testimony indicates that Caesar was the Triumvirate's architect, and that he formed it in 61 B.C.

On the other hand, Caesar's intention is not to instruct posterity as to the true circumstances of the Triumvirate's formation or, for that matter, about anything else: he is rather attempting throughout De Bello Gallico to make himself appear "formidable", to both friends and foes. A decision in 60 B.C. by the rivals Pompey and Crassus to jointly support Caesar's bid for the Consulate in 59 B.C. is no doubt a considerably more plausible account of the 
Triumvirate's origins. But this account diminishes the formidability of Caesar, and therefore the author of De Bello Gallico has no good reason to confirm it. I suspect, by the way, that the truth about the importance of the three men with respect to the Triumvirate is precisely the opposite of how it seems to us in retrospect: arranged in order of importance, the Triumvirate consisted of Crassus, Pompey, and Caesar, and not Caesar, Pompey, and Crassus. It is interesting that GRUEN supports the rather implausible notion of Caesar's constructive agency; ${ }^{24}$ apparently equally well disposed to Rome's two powerful rivals, Caesar seems like more of a go-between to me. ${ }^{25}$ But Caesar's account of the originative agency of Orgetorix, ${ }^{26}$ especially after the marriage he arranges between his daughter and Dumnorix leaves no doubt that the latter is Pompey, ${ }^{27}$ serves Caesar's purpose-once we understand his intention-despite the fact that the truth may well have been quite different.

In short: Caesar's Helvetian analogy suggests that he was responsible for the Triumvirate and that his agency bore fruit earlier than our other sources indicate. Regardless of one's attitude to the existence or applicability of the analogy, it cannot be denied that all of these sources are necessarily less well informed than Caesar himself about this particular matter. And Caesar's historical accuracy is irrelevant to the question of the analogy's applicability: his purpose is not to write history. Nor is it germane that the conspiracy of the Helvetian nobility that Orgetorix created in 61 B.C.- if indeed it actually existed-was something different from the inter-tribal triumvirate Caesar tells us the Helvetian created at some later time by joining with Dumnorix and Casticus. ${ }^{28}$ The important point is that Caesar's Orgetorix is Caesar's creation, and whatever truth there may be about Orgetorix in Caesar's narrative is incidental to Caesar's purpose. On the other hand, because Orgetorix is Caesar's created character-one of the means by which Caesar reveals his own formidability-every detail Caesar tells us about him needs to be carefully considered in the context of Caesar himself. My claim is that every one of those details reveals something about Caesar and, moreover, that each of those details makes Caesar more formidable. In fact, the experience of reading Caesar between
${ }^{24}$ Gruen 2009, p. 31:

"Caesar's determined efforts to bring Pompey and Crassus together (and even to add Cicero to the coalition) had broader objectives: implementation of a serious program of social and civic changes advantageous to the body politic as a whole. The trio carried substantial collective clout. But it was Caesar who had the agenda-and who drove the engine."

${ }^{25}$ Gruen 2009, p. 31: "What Crassus had to gain is less obvious." Cf. Gruen 1977, p. 124: "An improved understanding of Crassus will come when more attention is paid to what he did than to what he might have been doing behind the scenes.

Evidence, of course, is too scanty for a total picture."

${ }^{26}$ 1.3.7: Hac oratione adducti inter se fidem et ius iurandum dant et regno occupato per tres potentissimos ac firmissimos [populos totius Galliae] sese potiri posse sperant.

${ }^{27}$ 1.3.5: itemque Dumnorigi Haeduo, fratri Diviciaci, qui eo tempore principatum in civitate obtinebat ac maxime plebi acceptus erat, ut idem conaretur persuadet eique filiam suam in matrimonium dat. Without much support from others who have expressed opinions on the subject, I take qui to refer to Dumnorix, not Diviciacus.

${ }^{28}$ 1.3.3-4: Ad eas res conficiendas Orgetorix deligitur. Is sibi legationem ad civitates suscipit. In eo 
itinere persuadet Castico,

Catamantaloedis filio,

Sequano, cuius pater regnum

in Sequanis multos annos

obtinuerat et a senatu

populi Romani amicus appellatus erat, ut regnum in civitate sua occuparet, quod pater ante habuerit;

${ }^{29}$ 1.3.1-2 (brackets mine): [1] His rebus adducti et auctoritate Orgetorigis permoti constituerunt ea quae ad proficiscendum pertinerent comparare iumentorum et carrorum quam maximum numerum

coemere, [2] sementes quam maximas facere, ut in itinere copia frumenti suppeteret, [3] cum proximis civitatibus pacem et amicitiam confirmare. Ad eas res conficiendas [1-2]

biennium sibi satis esse duxerunt; [3] in tertium annum profectionem lege confirmant. Caesar's continuing use of triads is both striking and deliberate.

${ }^{30}$ 1.3.6: Perfacile factu esse illis probat conata perficere, propterea quod ipse suae civitatis imperium obtenturus esset: non esse dubium quin totius Galliae plurimum Helvetii possent; se suis copiis suoque exercitu illis regna conciliaturum confirmat. the lines in the manner proposed here is itself a formidable experience. The insiders-those warlike fellow-revolutionaries who are "in on" (understand) Caesar's ongoing joke-will be delighted and inspired by their fearless leader's clever recklessness and smooth audacity. And even more fearsomely, Caesar will once again have divided his enemies into three parts: (1) the trusting fools who will miss the joke entirely, (2) the Cassandra-like seers who, having allowed themselves to fear the worst while reading between the lines, will then try to rally his foes by using Caesar's hints as evidence, and finally (3) those whose indolence, good-natured incredulity, or boundless capacity for self-deception will lead them to join forces with the fools in the name of the facts, and oppose the lonely prophet who sees Caesar for what he is, i.e., "led on by a desire for kingly power."

One more aspect of Caesar's partially concealed selfidentification with Orgetorix deserves mention: Caesar's description of the effectiveness of Orgetorix as a speaker is particularly revealing. ${ }^{29}$ Like Caesar himself, Orgetorix relies on facts and personal authority in order to persuade: his auditors are his rebus adducti et auctoritate Orgetorigis permoti (1.3.1). It is therefore not by flowery speeches-like those of Cicerothat "his" audience is inspired: a calm recitation of the facts (his rebus is introduced at 1.2.4), combined with his auctoritas, creates inordinate passions among his chosen audience, those whom Caesar calls homines bellandi cupidi. ${ }^{30}$ To state the obvious: Caesar's De Bello Gallico has masqueraded for two thousand years as a calm and unadorned narrative of the factsof Caesar's res gestae - and the schoolmasters who have kept this text alive have counted on the fact that their pupils are, for the most part, little boys interested in war. Caesar's unaffected style as a writer, combined with the repeated demonstration of his skill in the face of his foes, appeals to the warlike, just as the speech of "Orgetorix" appealed to "his" civitas. Of course there is no "speech of Orgetorix" outside of Caesar's text, but there are still readers of that text-those who, even after two thousand years, are permoti autoritate Caesaris and his rebus adducti-who have been persuaded that Caesar's narrative is factual. Instead, as I am trying to demonstrate, it is far better understood in relation to Caesar's intention to present himself as "formidable." 


\section{CONCLUSION: FROM CATILINE TO CLODIUS}

Finally, there is Gerhard's sixth point to be considered: the parallel "failure" of the two Triumvirates. It is certainly an important question: why would the ambitious and ultimately successful Caesar-past master of analogy—make himself analogous to Orgetorix, who lost and was forced to make his plea in chains (1.4.1)? As indicated at the outset, it is only in response to this question that Gerhard stumbles: Caesar is not pointing forward to the Triumvirate's ultimate failure through dissolution, but rather to its origins in Cicero's Consulate (63 B.C.). A great advantage of seeing Cicero as Caesar's principal rival is that it offers a convenient template for detecting the interconnections between Cicero's various enemies. It is, of course, currently unfashionable to present Cicero in this light, and a scholar who seriously maintained today that Cicero was Caesar's principal rival would be thought not only to have grossly exaggerated Cicero's importance but even worse, to have erroneously diminished Caesar's. It is a curious thing about their rivalry: the more formidable Caesar is considered to have been from the start, the more astute Cicero, who recognized all this very early, will seem. But a world-historical Caesar requires Cicero to be an inconsequential windbag who had the shortsightedness to resist "the historically inevitable." 31

Consider a simpler point: Cicero is generally criticized or lampooned as a self-important braggart who praised himself profusely. What allows us to think that he exceeds the author of De Bello Gallico in this particular respect? Was there ever a greater braggart than Caesar, whose "Caesar" is the third-person hero of the famous book he lives by? But even if we underestimate Cicero, Caesar did not. Although it is unlikely that Caesar knew while writing de Bello Gallico that Cicero would later attribute both humanitas and virtus to his daughter Tullia, ${ }^{32}$ he accurately recognized that Cicero's considered allegiance was to humanitas and that even Cicero's conception of virtus was something very different from the strictly etymological and warlike manliness he attributes to the Helvetii, the Belgae, and by extension, to himself.
${ }^{31}$ Hegel 1956, p. 312-13.

$$
\begin{aligned}
& { }^{32} \text { See Cicero, ad Fam. } \\
& 14.11 \text { and McDonnell } \\
& 2006 \text {, p. 163-64. }
\end{aligned}
$$


${ }^{33}$ Sallust, Catilinae Coniuratio 52.16.

${ }^{34}$ Caesar does not mention Marcus Cicero in De Bello Gallico but he does mention his enemy Clodius at 7.1.1. The pro-Caesarian position among historians-see Gruen 1966 and more recently Tatum 1999presents Clodius as an independent agent: Caesar had nothing to do with Cicero's exile and indeed had spoken against it-cf.

Dio Cassius, 38.17.1-2 and Cicero's post reditum in Senatu, 32-having crossed the pomerium without as yet leaving Rome; on this, see Suetonius, Divus Iulus, 22.1 and Gelzer 1968, p. 97-8. Cicero's cumulative testimony quietly undermines this position from within: while permitting Caesar to appear to be a better citizen than he actually was, Cicero's own skills as a speaker remain hidden unless one realizes that he knows the truth about

Clodius (e.g. De haruspicum responsis, 45). As if to ensure that no student is fooled by Cicero's carefully constructed pose, all our post-Cicero

sources-Suetonius (Julius Caesar, 20.4), Velleius Paterculus (History of Rome, 2.45.2), Appian (Civil Wars, 2.2.14), Dio Cassius (38.11-12), and Plutarch (Life of Cicero, 30)_-offer useful indications that Clodius was working in Caesar's interest with respect to the removal of both Cicero and Cato; see StrachanDavidson 1894, p. 235-
With the Ciceronian template in mind, then, it is obvious that Antonius, Cicero's last opponent, was Caesar's avatar. Although it is considerably less obvious that Caesar himself was Catiline's avatar, this is nevertheless what the analogy of the Gallic Triumvirate suggests. By identifying himself with Orgetorix, Caesar is announcing his continuing loyalty to the failed Catiline, and unhesitatingly, if surreptitiously, identifying himself as upholding his only apparently lost cause. As presented in the pages of Sallustwho ought to know-the speech of Cato was predicated on precisely the suspicion that Caesar was a supporter of Catiline. ${ }^{33}$ But the crucial text here is not Caesar's speech for clemency in Sallust; it is Cicero's lost speech Pro Antonio (59 B.C.). Although his words are gone, the circumstances of its immediate reception survive: it was in response to this speech that Clodius-whose subsequent actions likewise bear eloquent witness to Catiline's enduring appeal-was transferred to the plebs so that he could run Cicero out of town as Tribune. ${ }^{34}$ It deserves emphasis that it was not until Cicero was driven from Rome that Caius Julius Caesar made his notorious Eintritt in der Geschichte by taking up his command in Gaul, as recorded in De Bello Gallico. Be that as it may, when Pro Antonio failed in a third way-it has not only failed to survive, but it led to its maker's exile-the supporters of Catiline marked the conviction of Antonius by covering the tomb of Catiline with flowers. ${ }^{35}$ As Shakespeare's tribune asked about a considerably later version of an all too similar story (Julius Caesar I. i. 54-55): "Do you now strew flowers in his way who comes in triumph over Pompey's blood?" It is the flowers of 59 B.C. that explain Caesar's willingness to identify himself with Orgetorix despite his "failure," and it will be as Catiline-reborn that Caesar will cross the Rubicon on the road from Gaul, cupiditate regni inductus.

Florianópolis, August 18, 2014 
BiBLIOGRAPHY

ALTMAN, W. H. F. Cicero and the Fourth Triumvirate: Gruen, Syme and Strasburger. In ALTMAN (ed.). Brill's Companion to the Reception of Cicero, 215-246. Leiden and Boston: Brill, 2015. p. 215-246.

BADIAN, E. From Iulii to Caesar. In GRIFFIN, M. (ed.). A Companion to Julius Caesar. Chichester: Wiley-Blackwell, 2009. p. 11-22.

CAESAR. C. Iulii Caesaris, Commentarii de bello gallico. Ed. F. Kraner, W. Dittenberger, H. Meusel. Hildesheim: Weidmann, 1913.

CAESAR. De Bello Gallico. In C. Iuli Caesaris Commentariorum I. Ed. Du Pontet. Oxford: Clarendon Press, 1890.

CICERO. M. Tulli Ciceronis Orationes VI. Ed. A. Clark. Oxford: Clarendon Press, 1911.

FIELDS, R. 2005. Voices of the Enemy: oratio recta and oratio obliqua in Caesar's De Bello Gallico. M.A. thesis. Georgia: University of Georgia, 2005.

FRÄNKEL, H. Wege und Formen frühgriechishen Denkens. Munich: Beck, 1955.

GELZER, M. Caesar: Politician and Statesman. Translated by Peter Needham. Cambridge, MA: Harvard University Press, 1968.

GERHARD, Y. Orgétorix l'Helvète et la Bellum Gallicum de César. Les Études classiques 51, p. 267-274, 1991.

GRIfFIN, M. (ed.). A Companion to Julius Caesar. Chichester: Wiley-Blackwell, 2009.

GRUEN, E. S. P. Clodius: Instrument or Independent Agent? Phoenix 20, p. 120-130, 1966.

1973.

. The Trial of C. Antonius. Latomus 32, p. 301-310, . The Last Generation of the Roman Republic. Berkeley: University of California Press, 1974.

. Licinius Crassus: A Review Article. American Journal of Ancient History 2, p. 117-128, 1977.
36 for the status quaestionis before Strasburger 1938. Despite the regrettable fact that the dominant position in AngloAmerican scholarship since the second half of the twentieth century has been pro-Caesar on this important point (see Altaman 2015), Caesar himself suggests the truth: the murder of Clodius (Clodii caede at 7.1.1) and the resulting tumult in Rome (urbano motu and in tantis

dissensionibus at 7.1.2) was accurately perceived by the Gauls as a check to Caesar's power and it was precisely this perception (hac impulsi occasione at 7.1.3) that temporarily put an end to quieta Gallia (7.1.1) in 52 B.C.

${ }^{35}$ See Gruen 1973. For their debt to Strasburger 1938, see Syme 1939, p. 25 n. 2, Syme 1964, p. 96-101, and Gruen 1974, p. 75 n. 117. 
GRUEN, E. S. P. Caesar as Politician. In GRIFFIN, M. (ed.). A Companion to Julius Caesar. Chichester: Wiley-Blackwell, 2009. p. 23-36.

HEGEL, G. W. F. The Philosophy of History. Translated by J. Sibree. Dover: New York, 1956.

HOHL, E. Review of VOGT, Die römische Republik in Römische Geschichte, erste Hälfte. Gnomon 9, no. 3, p. 141-145, 1933. HOLMES, T. R. Caesar's Conquest of Gaul. Second edition. Oxford: Clarendon Press, 1911.

MCDONNELL, M. Roman Manliness: Virtus and the Roman Republic. Cambridge, UK: Cambridge University Press, 2006. RIGGSBY, A. Caesar in Gaul and Rome: War in Words. Austin: University of Texas Press, 2006.

STRACHAN-DAVIDSON, J. L. Cicero and the Fall of the Roman Republic. London: Putnam's Sons, 1994.

STRASBURGER, H. Caesars Eintritt in der Geschichte. Darmstadt: Wissenschaftliche Buchgesellschaft, 1938.

SYME, R. The Roman Revolution. Oxford: Oxford University Press, 1939.

. Sallust. Berkeley: University of California Press, 1964.

TATUM, J. The Patrician Tribune: Publius Clodius Pulcher. Chapel Hill: University of North Carolina Press, 1999.

TORIGIAN, C. The ^óyos of Caesar's Bellum Gallicum, especially as revealed in its first five chapters. In WELCH, K., POWELL, A (eds.). Julius Caesar as Artful Reporter: The War Commentaries as Political Instruments. London: Duckworth, 1998. p. 45-60.

VOGT, J. Divide et impera - die angebliche Maxime der römischen Imperialismus. In VOGT, J. Orbis: Ausgewählthe Schriften zur Geschichte des Altertums. Freiburg: Herder, 1960. p. 199-218.

WELCH, K., POWELL, A. (eds.). Julius Caesar as Artful Reporter: The War Commentaries as Political Instruments. London: Duckworth, 1998.]] 